\title{
The Real North Korea: Life and Politics in the Failed Stalinist Utopia. By Andrei Lankov. New York: Oxford University Press, 2013. xv, 283 pp [ISBN 9780199964291]
}

Over the years, Andrei N. Lankov has become firmly established in English-language academia as a preeminent scholar of North Korea, matched only by few in his breadth of knowledge, linguistic fluency, and prolific research contributions. It would be no surprise, then, if his 2013 The Real North Korea becomes one of the most informative and useful guidelines available over the coming years not only for non-specialist readers interested in North Korea, but also for dedicated researchers of modern Korean history and society. Divided into six chapters which chronicle the history of the Democratic People's Republic of Korea and lay out some possible political measures for the present along with future scenarios, The Real North Korea sets out to explain "the inner logic of North Korean behavior" stemming from "long-term developments" in North Korean society (xii). The book's discussion of "ways to mitigate the problems and control the damage" on the divided Korean Peninsula (xiv) may also be a useful reference for those interested in contemplating North Korea's future.

Such potential contributions notwithstanding, the book is fraught with

* University of California, Los Angeles. 
simplistic characterizations and teleological narratives that will likely reinforce unproductive received perceptions regarding North Korea. The author asserts, as mainstream media and political commentary have quipped for decades, that North Korean rulers "sincerely believe that their current policy has no alternatives" (xv), raising questions as to the point of adding this book to our reading list. To make matters worse, Lankov seems to feel no qualms in presenting his value-laden interpretations as the truth, when they in all likelihood often hinder the reader from grasping the history of North Korea in a nuanced manner. Hence, a critical reader might legitimately wonder whether The Real North Korea indeed narrates the "real" dimensions of North Korea.

A brief biographical review of the author should facilitate our understanding of this book's historiographical significance. Since the early 1990s, Andrei Lankov has written a number of crucial works on North Korean political history in both Korean and English. After teaching at Australian National University between 1996 and 2004, he returned to Korea to teach at Kookmin University, where he remains today. His rise to fame as a top-notch North Korean specialist is not only attributable to his expertise on the factional struggles that marked the history of premodern Korea, but also coincided with the sudden availability of a massive quantity of primary sources on North Korea from key Russian archives. It would be no exaggeration to say that his 1995 Korean-language book, Soryŏn ŭi charyo ro pon puk'an hyŏndae jŏngch'isa [North Korean Contemporary Political History Based on Russian Sources], is a "must read" for those interested in North Korea's early political history. He subsequently published two major English-language books-From Stalin to Kim Il Sung (2002) and Crisis in North Korea (2005)—attaining enormous prestige as one of the few respectable empirically-oriented scholars of North Korean history. Tellingly, both books depict North Korean politics as a series of factional struggles, with the latter drawing upon previously untapped Archive of Russian Federation Foreign Policy (AVPRF) materials to cover the fateful year of 1956 when there was an attempted coup by the so-called "August Group" against Kim Il Sung. While 
Lankov's focus shifted to more contemporary developments in the 2010s, he has continued to contribute to the field by publicizing Russian State Archive of Socio-Political History (RGASPI) materials. ${ }^{1}$ Seen in light of this illustrious career, The Real North Korea undoubtedly represents cutting-edge scholarship that epitomizes expertise accumulated over the course of three decades.

Intriguingly, the book's organization reflects Lankov's academic trajectory. Chapters 1 and 2 summarize the political history of North Korea under the rule of Kim Il Sung and Kim Jong Il. After discussing important periods such as Kim Il Sung's early rise under Soviet tutelage in the 1940 s, the Korean War and its aftermath in the 1950s, and the emergence of Juche as state ideology and the Sino-Soviet split in the 1960s, Chapter 1 places special emphasis on the repressive dimension of North Korea's political system and its personality cult, both of which have given North Korea a bad name in the international community. After setting the tone in these early chapters, Chapters 3 and 4 offer narratives of the possible rationales of North Korean leadership in both the domestic and international realms at the dawn of the twenty-first century. In these chapters, Lankov attempts to explain "North Korean behavior" as centering almost exclusively on survival and stability, both of which make North Korea much less special from other countries. Chapters 5 and 6 suggest limited but actionable measures regarding "the peculiar case of North Korea," in which "in the long run the current regime is doomed" $(207 ; 234)$. In order to alleviate the Armageddon expected to follow unification, the author hints at the promise of working with North Korean refugees in South Korea, who are said to have "at least three roles" to play in future develop-

1 Andrey Nikolayevich Lan'kov, Soryŏn gongsandang gwa puk'an munje: Soryŏn gongsandang chŏngch'igug kyŏlchŏngsŏ(1945-1952). Trans. Chŏn Hyŏnsu (Daegu: Kyŏngbuk taehakkyo ch'ulp'anbu, 2014). 
ments (231). ${ }^{2}$ Overall, the book is devoted to recommending how outsiders should act towards - or against - North Korea by providing an account of its past, present, and possible futures. Most readers should do well by jumping to the parts that correspond to his or her curiosity.

To this reviewer - one of many who has benefited over the years from Lankov's scholarship - two primary points merit discussion in the hope of someday reading a better sequel to The Real North Korea. First, a number of concepts and notions used in this book are vague and confusing. Indeed, a number of characterizations lacking proper substantiation appear throughout the book. For example, as the subtitle indicates, North Korea is often identified as a "Stalinist" country infused through and through with "Stalinism." What, then, might these terms mean? Regrettably, I was unable to find any clear definition of either "Stalinism" or "Stalinist" save for a few sentences upon which the reader is forced to rely on to interpret the terms (xii; $12 ; 18 ; 44 ; 26)$. Surprisingly, this important concept is then combined with other adjectives, resulting in a proliferation of even more abstract and complicated ideas that take much effort to untangle. Examples include "the archetypal National Stalinist regime" a "hereditary Stalinist dictatorship," and a "hyper-Stalinist economy" (1; 29; 62-3; 67). Do these terms enable us to better understand North Korea? The reader will be hard-pressed to find the answer within the pages of this book. This lack of clarity is also seen in other adjectives such as "liberal" and "underdeveloped." The author could have done better by referring to works undertaken by Soviet historians that cover the various aspects of Stalinism as manifested in the 1930s and the late-Stalinism of the 1940s, as well as those by intellectual historians devoted to contextualizing the variegated usages of specific historical terms.

Second, the author's fixation on the failures and inefficiencies of North

2 Those suggested roles by refugees include: to serve as an additional as well as efficient window through which efforts could reach "the average North Koreans"; to act on what they have learned from South Korea in their Northern home; to become "role models for the North Korean refugee community." 
Korea lead one to question the balance of The Real North Korea's overall perspective. Coupled with the author's teleological inclination towards a Seoul-led, capitalist unification, this view unmistakably captures the gist of the author's main argument. But is the current North Korean system not only "both unsustainable and unreformable," but also "a complete mess" (187; 257), as the author evaluates? How would "real" North Koreans view the idea of appointing "some outside government" to run a transitional North Korea, as the author seems to advocate? I also wonder whether such bold and hasty predictions could help the reader situate "the inner logic of North Korean behavior" in historical purview. Lankov's general approach, widely shared by narratives that highlight "the myriad failings of Sovietization" in Eastern European countries, ${ }^{3}$ is understandable but merits serious reconsideration. We must ask whether North Korea merely represents a social experiment that is "fatally flawed" (75). Even if true, under what context is such a diagnosis justified academically? It is also interesting to note the book's comparison of North Korea as a sheer failure with "one of the greatest success stories in the history of capitalism" supposedly embodied by South Korea, along with "other nations of East Asia" (158; 258). I wonder what the author has in mind when he speaks of "success," given the rampant socioeconomic problems that afflict those countries such as gender inequality, high rates of suicide, adverse working conditions, and declining birthrates, to name a few. In a nutshell, the reader will find "the real" North Korea only to the extent that the book's conventionality allows us to do so.

In conclusion, although this book is destined to become an authoritative resource for a wide range of readers, it is by no means a stretch to say that many key portions are highly debatable at best. This reviewer worries that by circumscribing our view within a narrative of deficiencies, inefficiencies, and failures, this otherwise well-written book might only reinforce perceptions of North Korea that, more often than not, are ahistorical, bi-

3 Elidor Mëhilli. From Stalin to Mao: Albania and the Socialist World (Ithaca: Cornell University Press, 2017), 5. 
ased, and erroneous. It is also critical that the tone and tenor of the book tends to discourage the reader from reconsidering existing narratives of North Korean history. By way of illustration, without the people's passion, support, and hope for building a better polity, would Kim Il Sung have been able to build North Korean society from the ground-up relying solely upon violent and harsh measures, as the subtitle of Chapter 1 suggests? ${ }^{4}$ Regrettably, there seems to be almost no place in this book for the voice, however small and weak, of the North Korean people to be heard. In line with too many North Korea-related publications, their presence is constantly erased, muted, and ignored in The Real North Korea. It is of the utmost urgency to pay attention to such "real" North Koreans of the past.

4 The trend to equate the communist regime's governance with violence and terror was already commonplace in the 1920s and 1930s. Stalin rebutted this prevalent misunderstanding in a conversation with German-Swiss author Emil Ludwig. See "Beseda s nemetskim pisatelem Emilem Ludwigem," 13 December 1931, in Stalin, Sochineniia, vol. 13. (Moscow: Gosudarstvennoye izdatel'stvo politicheskoy literatury, 1951), 109. http://grachev62.narod.ru/stalin/t13/t13_19.htm accessed 14 July 2019. 